\title{
Н.Д. Орищин
}

Львівський національний медичний університет імені Данила Галицького

КЗ ЛОР «Львівський обласний клінічний лікувально-діагностичний кардіологічний центр»

\section{Небактерійний тромботичний ендокардит як причина системної емболії}

\begin{abstract}
У статті описаний клінічний випадок небактерійного тромботичного ендокардиту в пацієнтки з ішемічним інсультом емболічного походження. Методи візуалізації (трансторакальна та черезстравохідна ехокардіографія) дозволили виявити специфічні ознаки тромботичних вегетацій на мітральному та аортальному клапанах серця. Лабораторні методи діагностики (посів крові, серологічне дослідження) заперечили інфекційний ендокардит як причину вегетацій. Унаслідок діагностичного пошуку (комп'ютерна томографія) виявлено первинний новоутвір легень із вторинними вогнищами в кістковій системі. Представлений випадок демонструє потребу настороженості щодо небактерійного тромботичного ендокардиту в пацієнтів з явищами системної емболії та в специфічних групах хворих (автоімунна й онкологічна патологія).
\end{abstract}

Ключові слова: небактерійний тромботичний ендокардит, марантичний ендокардит, ехокардіографія, системна емболія.

Посилання: Орищин Н.Д. Небактерійний тромботичний ендокардит як причина системної емболії // Кардіохірургія та інтервенційна кардіологія.- 2020.- № 3.- С. 26-32.

To cite this article: Oryshchyn ND. Nonbacterial thrombotic endocarditis as a cause of systemic embolism. Cardiac Surgery and Interventional Cardiology. 2020;3(30):26-32 (in Ukr.).

$\mathbf{H}$ ебактерійний тромботичний ендокардит (НБТЕ) - це патологія серцевих клапанів вторинного походження, яка загрожує повторними системними емболіями. Основною ознакою НБТЕ вважають наявність стерильних тромботичних «бородавкоподібних» вегетацій на клапанах лівої половини серця в пацієнта без ознак бактеріємії. Цей вид ендокардиту - нерідкісне ускладнення онкологічної патології та автоімунних захворювань. Діагностика НБТЕ утруднена через невеликі розміри вегетацій і вимагає високої настороженості в певних групах пацієнтів. Важливо пам'ятати про ймовірність НБТЕ в пацієнтів із системними емболіями незрозумілого походження, а виявлення цієї патології може допомогти у встановленні основного діагнозу пацієнта. В описаному випадку представлено особливості діагностики й лікування НБТЕ в пацієнтки 3 ішемічним інсультом емболічного походження на тлі онкологічної патології.

\section{Клінічний випадок}

Пацієнтка віком 48 років госпіталізована до Львівського обласного кардіологічного центру 3 явищами лівобічної геміплегії внаслідок ішемічного інсульту в басейні правої середньої мозкової артерії з підозрою на септичний ендокардит мітрального й аортального клапанів.

При попередньому обстеженні з приводу причини інсульту не виявлено патології сонних чи вертебральних артерій, артеріальної гіпертензії, епізодів фібриляції передсердь. При гематологічному обстеженні патологічної тромбофілії не знайдено. При ехокардіографії встановлено ознаки ураження стулок аортального й мітрального клапанів (потовщення), з помірною недостатністю. Скерована до кардіологічної клініки з підозрою на інфекційний ендокардит (IE).

Скарги при госпіталізації на рухові порушення (геміпарез). Об'єктивний стан хворої 
визначається неврологічною симптоматикою. Задовільного живлення, шкірні покриви блідо-рожеві, теплі, сухі. Температура тіла $36,6{ }^{\circ} \mathrm{C}$. Акроціанозу не виявлено. Грудна клітка правильної форми, дихання везикулярне з частотою 18 за 1 хв. Серце - тони ритмічні, частота серцевих скорочень 74 за 1 хв. Артеріальний тиск - 130/85 мм рт. ст. М'який систолічний шум на верхівці і в точці Боткіна. Легкий діастолічний шум над аортою, проводиться вздовж лівого краю груднини. При фізикальному обстеженні внутрішніх органів патологічних змін не виявлено. Печінка не виступає 3-під реберної дуги, пальпація живота не болюча. Симптом Пастернацького негативний.

Лабораторне обстеження. Загальний аналіз крові: гемоглобін - 137 г/л, еритроцити $4,2 \cdot 10^{12} /$ л, тромбоцити - $168 \cdot 10^{9} /$ л, лейкоцити $11 \cdot 10^{9} /$ л, еозини - $2 \%$, палички - $2 \%$, сегментоядерні - 68 \%, лімфоцити - $24 \%$, моноцити $4 \%$, ШОЕ - 2 мм/год. Коагулограма: протромбіновий час - 18 с, протромбіновий індекс - $88 \%$, загальний фібриноген - 4 г/л, гематокрит $-0,52$. Біохімічні аналізи: креатинін - 100,6 мкмоль/л, сечовина - 8,2 ммоль/л, АСТ - 31,8 од/л, АЛТ 60,6 од/л, глюкоза крові - 4,8 ммоль/л, білірубін - 9,8 мкмоль/л.

ЕКГ - ритм синусовий, електрична вісь серця не відхилена, вольтаж достатній, неспецифічні зміни сегмента ST.

При ультрасонографії внутрішніх органів патологічних змін не виявлено.

При трансторакальній ехокардіографії (TTE) виявлено нормальні розміри камер серця: ліве передсердя - 36 мм, лівий шлуночок (ЛШ) 45 мм, міжшлуночкова перегородка - 11 мм, задня стінка ЛШ - 10 мм, правий шлуночок 20 мм. Фракція викиду - 70 \%. Систолічна та діастолічна функції ЛШ у нормі. Встановлено потовщення стулок мітрального й аортального клапанів з помірною мітральною і аортальною недостатністю. Слід відзначити, що за 3 місяці до госпіталізації пацієнтка була обстежена за допомогою ТTE $з$ приводу підозри на ревматизм (болі в хребті), виявлено слідову мітральну недостатність, мінімальні зміни стулок мітрального клапана (МК), відсутні патологічні зміни аортального клапана (АК). Потовщення стулок клапанів підтвердило підозру на IE, однак у пацієнтки не було клінічних симптомів інфекційного процесу та лабораторних ознак запалення. Для уточнення характеру змін клапанів виконано черезстравохідну ехокардіографію за допомогою апарата Mindray (Китай).

При черезстравохідній ехокардіографії виявлено малі бородавкоподібні утвори на вхід- ній поверхні обох стулок МК (діаметром 3 та 8 мм) уздовж лінії коаптації (рuс. 1). Утвори мали правильну форму і гладеньку поверхню. Візуалізували невеличкий утвір на правій коронарній стулці АК (діаметр 5 мм) і потовщення стулок АК (рис. 2, 3). Підтверджено помірний ступінь недостатності стулок МК та АК (puc. 4, 5). Розміри камер серця та скоротливість ЛШ збережені.

Повторні посіви крові на гемокультуру не виявили росту патологічних збудників. Серологічне обстеження на низку інфекційних агентів мало негативний результат, С-реактивний протеїн у межах норми.

На основі характерного вигляду вегетацій i відсутності клініки IE, негативних результатів посівів крові та серологічного дослідження крові запідозрили діагноз НБТЕ. Розпочато антикоагулянтну терапію низькомолекулярними гепаринами (еноксапарин).

Виконали обстеження пацієнтки на можливі причини НБТЕ (автоімунну та онкологічну патологію).

Провели обстеження крові на показники стану імунної системи (RoSS-F 52, La/SS-B, Scl70, dsDNA, MPO, CENP-B, AMA-M2Б, ANAпрофіль та інші). Усі результати негативні.

Виконали комп'ютерну томографію (КТ) грудної, черевної порожнин та порожнини тазу 3 контрастним підсиленням (контрастування

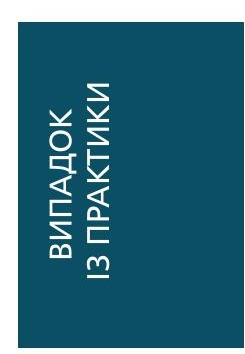

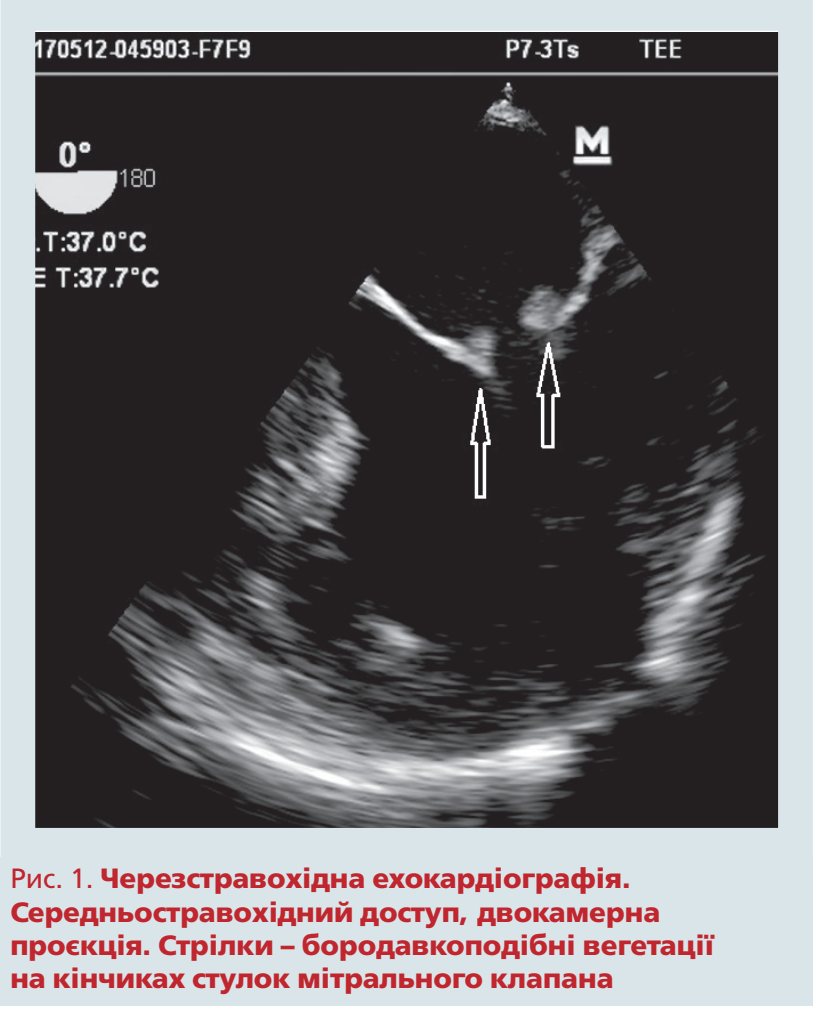


томогексол - 350 мг, 80 мл). Обстеження виконане на 128-зрізовому томографі TSX-101A Agulion (Toshiba Medical System, Японія). Висновок: периферичний об'ємний утвір верхньої частки лівої легені. Вторинне ураження бронхопульмонального і підбіфуркаційного лімфатичних вузлів. Множинні дифузні остеосклеротичні вогнища в тілах хребців шийного, грудного та поперекового відділів хребта, в кістках тазу, груднині, лівій ключиці, в головках плечових та стегнових кісток, підзора на вторинне ураження.

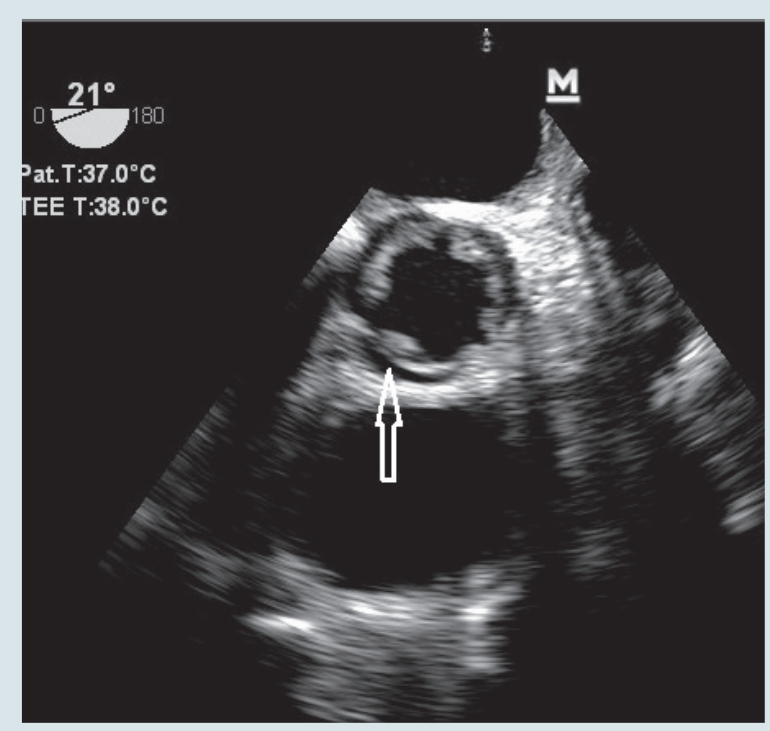

Рис. 2. Черезстравохідна ехокардіографія. Середньостравохідний доступ, проєкція короткої осі. Потовщені стулки аортального клапана, стрілка - вегетація на правій коронарній стулці аортального клапана

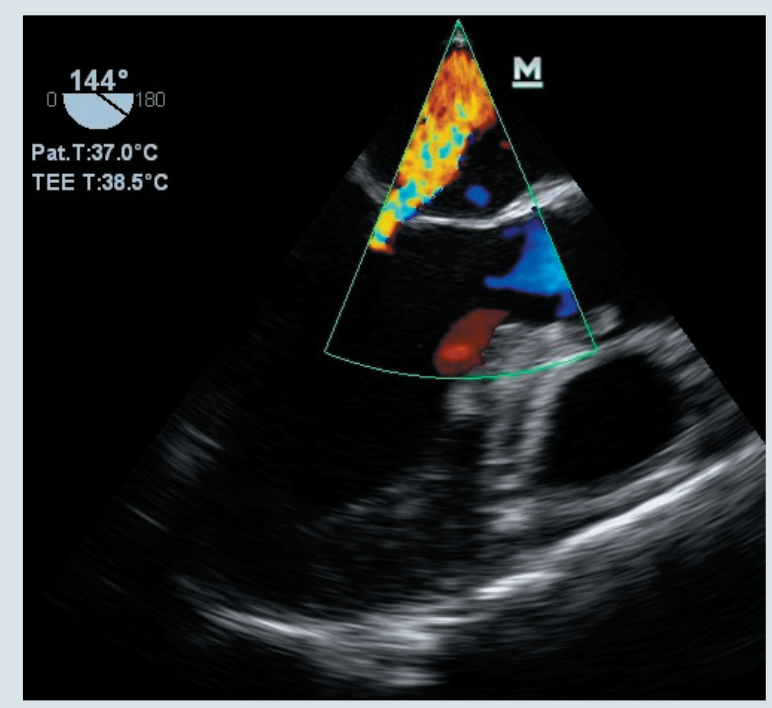

Рис. 4. Черезстравохідна ехокардіографія, кольорова допплерографія потоку мітральної регургітації. Помірна недостатність мітрального клапана
Виконали позитронно-емісійну томографію (ПЕТ): у S3 правої легені візуалізується вузловий утвір $24 \times 19$ мм з підвищеною метаболічною активністю, гіперметаболічні лімфатичні вузли (шийні, надключичні, паратрахеальні та внутрішньогрудні). Практично в усіх кістках скелету візуалізуються множинні остеобластичні високометаболічні вогнища, характерні для вторинного ураження. Висновок: зміни в легенях, лімфовузлах та кістках можуть бути розцінені як первинний рак правої легені 3

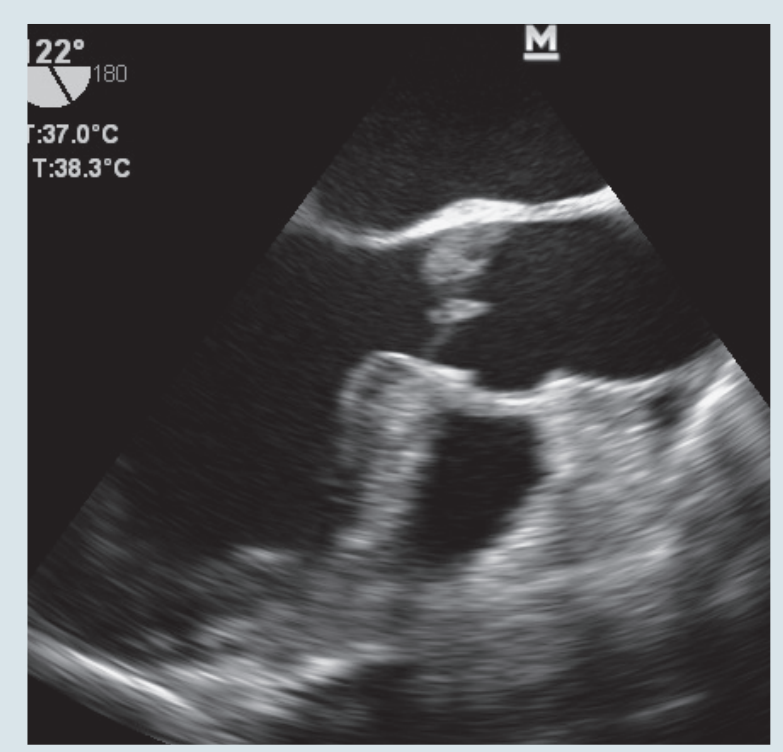

Рис. 3. Черезстравохідна ехокардіографія.

Середньостравохідний доступ, проєкція довгої осі.

Потовщені стулки аортального клапана

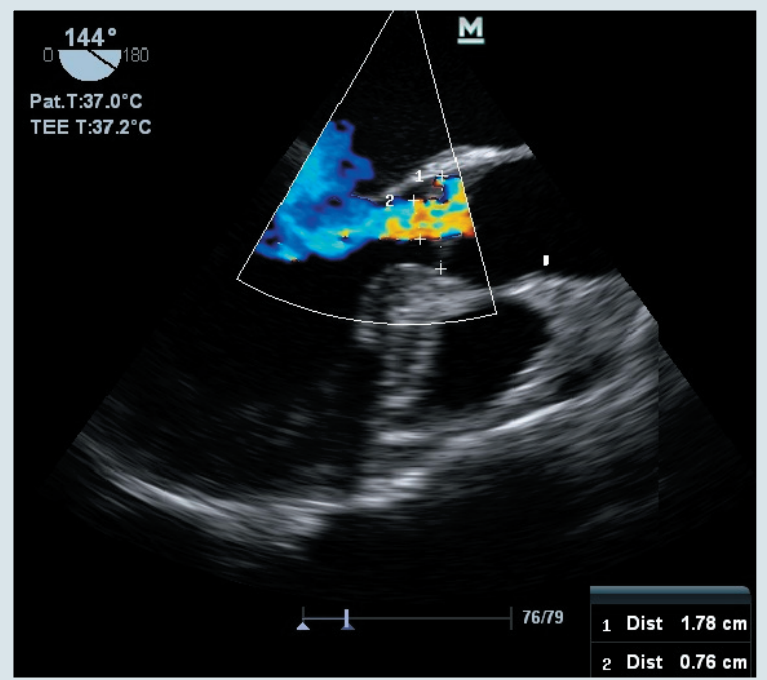

Рис. 5. Черезстравохідна ехокардіографія, кольорова допплерографія потоку аортальної регургітації. Ширина потоку регургітації у вихідному тракті лівого шлуночка свідчить про помірну недостатність аортального клапана 
вторинним ураженням лімфовузлів та кісток скелету.

Оскільки дослідження пацієнтки дозволило встановити діагноз раку легень, хвора виписана для подальшого лікування онкологічного процесу з рекомендаціями щодо лікування серцевої патології.

\section{Обговорення}

Хоча НБТЕ - це не рідкісна патологія, однак прижиттєва його діагностика є недостатньою, часто запізнілою, а серед лікарів діагноз НБТЕ залишається маловідомим. Основний вияв хвороби - стерильні вегетації на клапанах серця, переважно лівої половини, які складаються 3 тромбоцитів і фібрину. Розміри вегетацій звичайно малі, сягають кількох міліметрів, тому розпізнати їх при ТТЕ складно. Запальний процес ендокарда клапанів при цій патології мінімальний, вегетації крихкі, легко залишають місце утворення і мігрують у кров’яному руслі. Таким чином, основним ускладненням НБТЕ є емболії серцевого походження різної локалізації, найчастіше мозкові.

Уперше тромботичні стерильні вегетації на клапанах описали Лібман і Сакс у 1924 р., у представлених випадках ендокардит був ускладненням системного червоного вовчака (СЧВ). Згодом, у 1936 p., Gross i Fiedberg дали цій хворобі назву НБТЕ, яка відображає сутність патологіi: вегетації не містять бактерій, при цьому багаті на тромбоцити [1]. Причиною НБТЕ є не лише СЧВ з антифосфоліпідними антитілами, а й інші види набутого та ідіопатичного антифосфоліпідного синдрому і різна патологія, пов’язана 3 ушкодженням ендотелію та підвищеною коагуляцією крові. Крім того, серед причин велика частка належить онкологічній патології, у цьому випадку НБТЕ ще називають «марантичним» ендокардитом.

Частота виявлення вегетацій, зумовлених НБТЕ, за даними автопсій становить від 1,08 до 9,3% у популяції [1, 12]. При цільовому скринінгу пацієнтів 3 онкологічною патологією ехокардіографічні ознаки НБТЕ виявили у $19 \%$ [4]. Інша група пацієнтів з високою схильністю до НБТЕ - це хворі з колагенозами (особливо із СЧВ), автоімунними хворобами, гіперкоагуляційними станами (антифосфоліпідний синдром), хворобою Бехчета [17]. Частота НБТЕ в пацієнтів із антифосфоліпідним синдромом становить 32 \% [16]. Схильність до НБТЕ підвищують такі хронічні хвороби, як туберкульоз, СНІД, уремія, а також променева терапія [1].
У патогенезі НБТЕ головну роль відіграє ушкодження ендотелію та осідання тромбоцитів на оголеній сполучній тканині в місцях пошкодження ендотелію. Пусковими факторами процесу можуть бути імунні комплекси, гіпоксія, гіперкоагуляція та карциноматоз.

Як при СЧВ, так і при антифосфоліпідному синдромі вегетації є стерильними і мають фібринотромбоцитарний характер, формуються на клапанах лівої половини серця. В основі тромботичних нашарувань на клапанах при імуногістохімічному аналізі виявляють комплекси імуноглобулінів 3 комплементом. Ці вегетації є бородавкоподібними, фіксованими, вони розташовані на вхідній поверхні клапана (з боку «напливу» крові) [17]. Часом такий ендокардит призводить до значного порушення функції клапана і вимагає хірургічної корекції $[11,17]$.

Серед онкологічної патології особливу схильність до такого ускладнення, як НБТЕ, мають муцин-продукувальні аденокарциноми (це стосується аденокарциноми легень, яєчників, підшлункової залози та шлунка) і промієлопроліферативні захворювання крові. Пусковими патогенетичними механізмами в цих випадках вважають вивільнення фактора некрозу пухлини $\alpha$, інтерлейкіну-1 та інтерлейкіну-6 та їх пошкоджувальний вплив на структуру ендотелію клапанів [20, 21]. Іншим важливим елементом формування стерильних вегетацій при раку є гіперкоагуляція.

Вегетації при НБТЕ дуже крихкі (більше ніж при IE), оскільки місцевий запальний процес виражений слабко, а переважають явища гіперкоагуляції та налипання тромбоцитів.

Клініка. Клініка НБТЕ доволі скупа: на відміну від інших форм ендокардиту, НБТЕ рідко призводить до гемодинамічно значущої дисфункції клапана і не викликає таких симптомів, як лихоманка чи пітливість. Маніфестацією НБТЕ є системні емболії, часто множинні або повторні, це зумовлює особлива крихкість небактеріальних вегетацій та їхня здатність легко зміщуватися 3 місця формування (стулок клапанів) у просвіт судини і далі з потоком крові.

Найчастішими місцями локалізації системної емболії є: мозкові судини (головний мозок), вінцеві судини, селезінка, нирки, периферичні судини кінцівок. Найпоширенішим ускладненням (у 30 \% пацієнтів з НБТЕ) є ішемічний інсульт ембологенного походження [1]. Припущення щодо причини кардіоемболічного інсульту можна зробити ще під час МРТ головного мозку: інсульти при НБТЕ частіше є множинними, а при IE це звичайно одне вогнище. Рідкісним, але небезпечним ускладненням НБТЕ є емболія у 
вінцеві артерії з розвитком інфаркту міокарда. Часто до встановлення діагнозу НБТЕ в пацієнта вже відбулося кілька емболічних подій у системі великого кола кровообігу [6, 8, 9].

Діагноз. Діагностика НБТЕ починається здебільшого, як і в нашому випадку, з пошуку причини системної емболії кардіального походження. У сучасних настановах для виявлення НБТЕ рекомендовані як трансторакальна, так і черезстравохідна ехокардіографія. Початковим методом діагностики є ТTЕ, результати якої вказують на ураження клапанів, однак часто не дають змоги диференціювати природу виявлених змін $[16,19]$. Для уточнення характеру змін необхідна черезстравохідна ехокардіографія, а для диференціації з IE - клінічні дані та низка лабораторних досліджень на виявлення патогенного збудника.

Діагностичною ознакою НБТЕ є виявлення при ехокардіографії малих, «сидячих» бородавкоподібних вегетацій на кінчиках клапанів (мітрального та/або аортального). Вегетації розташовані на вхідній поверхні клапанів, як і при IE, однак, на відміну від справжніх вегетацій, ці нарости мають гладеньку поверхню та округлу форму. Для справжніх бактеріальних вегетацій характерна нерівна «волохата» поверхня, часто великі розміри (ембологенними вважають вегетації при IE розміром понад 10 мм) [7]. При НБТЕ вегетації менш аморфні, ніж при IE, мають чіткіші контури, не супроводжуються деструкцією клапанів.

Необхідним етапом діагностики НБТЕ є кількаразовий посів крові на гемокультуру, включно iз серологічним способом пошуку таких збудників, як бактерії з групи НАCEK, Coxiella, Legionella, Chlamydia (ПЛР) та оцінювання запальних показників (С-реактивний протеїн). Негативний результат таких досліджень дозволяє запідозрити НБТЕ.

Після заперечення інфекційного походження вегетацій і підозрі на НБТЕ слід виконувати пошук основної хвороби, яка стала його причиною: скринінг на антикардіоліпінові антитіла, антинуклеарні антитіла, тести на автоімунні хвороби та пошук онкологічної патології [7].

Для диференціації причини ендокардиту пропонують використовувати ПЕТ з ФДГ: інфекційні вегетації за наявності запалення накопичують ФДГ, на відміну від небактеріальних $[1,7]$.

У представленому випадку, незважаючи на відсутність клініки септичного ендокардиту (гарячки, пітливості, ознак серцевої недостатності) виконали інтенсивний пошук інфекційного збудника, результат посівів крові та серологічного дослідження крові був негативним. Тому наступним кроком у діагностичному пошуку було обстеження на предмет виявлення онкологічної та автоімунної патології (КТ, ПЕТ, лабораторна автоімунна панель), що й привело до встановлення діагнозу.

Онкологія та інсульт. НБТЕ є частим ускладненням раку, серед причин інсульту у хворих з онкопатологією до 8,2 \% становить НБТЕ, інші $39 \%$ - це так звані криптогенні інсульти, значна частина яких може бути наслідком недіагностованого НБТЕ [22]. Зв'язок раку з тромбоемболічним синдромом описаний давно і має назву синдрому Трюссо за прізвищем автора. До $50 \%$ пацієнтів із заавансованою стадією раку мають виявлені венозні тромбози й емболії на розтині [15]. Артеріальні емболії в таких пацієнтів трапляються рідше, але мають рецидивний характер і часто власне вони стають причиною смерті пацієнта $[6,8,9,14,18] .3$ великою ймовірністю, основна причина артеріальних емболій при раку - НБТЕ, або марантичний ендокардит $[6,8,9,18]$, хоча можливі й інші причини: IE, зумовлений імуносупресивним впливом лікування, емболії шматочками метастатичних пухлин 3 камер серця. При аналізі причини інсульту у 256 пацієнтів із раком встановлено, що серед хворих із карциномою НБТЕ є причиною мозкової емболії у 18,5 \% [5]. Це наводить на висновок, що в пацієнтів з онкопатологією необхідне особливо уважне ехокардіографічне обстеження перед лікуванням та впродовж нього з ретельним обстеженням стулок клапанів, а у випадку виявлення «нового» потовщення стулок чи дисфункції клапана - черезстравохідне обстеження, яке дозволяє встановити діагноз (як в описаному випадку).

Лікування НБТЕ має дві складові: антикоагулянтну терапію та лікування основного процесу, який викликав формування стерильних вегетацій: автоімунної хвороби або раку. Слід зазначити, що НБТЕ - це ознака злоякісного процесу в заавансованій фазі (як у цьому випадку, оскільки в пацієнтки виявлено віддалені метастази в кістки) [15]. Однак і в таких випадках можливе досягнення позитивного результату від комплексного лікування основної хвороби разом з антикоагуляцією [8].

Немає жодного рандомізованого дослідження, яке стало би основою рекомендацій з приводу лікування НБТЕ. Настанови з лікування IE Свропейського товариства кардіологів наголошують на важливості диференціації IE та НБТЕ, які мають різні лікувальні підходи: у той час як антикоагулянти протипоказані при IE, то при НБТЕ це один із методів лікування вегетацій і профілактики наступних емболіч- 
них епізодів [7]. На цей час найбільш обгрунтованим виглядає призначення підшкірно низькомолекулярних гепаринів (НМГ) у терапевтичних дозах. Можливим кроком є перехід із НМГ на варфарин або прямі пероральні антикоагулянти [7].

Особливо це стосується НБТЕ, зумовленого онкологічним процесом. При ішемічному інсульті різного генезу в онкології рекомендують починати лікування з антикоагуляції НМГ [15]. Результати досліджень 3 венозних тромбоемболій переносять на лікування артеріальних при НБТЕ, враховуючи, що за складом тромботичні нашарування на клапанах при цьому є схожими до венозних тромбів [15]. За останніми настановами, для антикоагуляції при венозних тромбоемболіях у хворих з онкопатологією, окрім НМГ, можна використовувати прямі пероральні антикоагулянти (едоксабан та ривароксабан) $[9,10]$.

Хірургічне лікування НБТЕ доцільне в тих небагатьох пацієнтів, у яких НБТЕ зумовлюе формування гемодинамічно значущої клапанної вади, згідно з рекомендаціями 3 приводу IE [7, 11]. Лікування патології, яка стала причиною НБТЕ, очевидно, є необхідним для того, щоб зупинити прогресування процесу.

Конфлікту інтересів немає.

\section{Література}

1. Asopa S., Patel A., Khan O.A. et al. Non-bacterial thrombotic endocarditis // Eur. J. Cardiothorac. Surg.- 2007.- Vol. 32 (5).P. 696-701. doi: 10.1016/j.ejcts.2007.07.029.

2. Celeste F., Muratori M., Mapelli M., Pepi M. The evolving role and use of echocardiography in the evaluation of cardiac source of embolism // J. Cardiovasc. Echography.- 2017.Vol. 27.- P. 33-44.

3. Detremerie C., Timmermans F., De Pauw M. et al. Stroke due to non-bacterial thrombotic endocarditis as initial presentation of breast invasive ductal carcinoma // Acta Clin. Belg.2016.- Vol. 72 (4).- P. 268-273. doi: 10.1080/17843286.2016. 1219012.

4. Edoute Y., Haim N., Rinkevich D. et al. Cardiac valvular vegetations in cancer patients: a prospective echocardiographic study of 200 patients // Am. J. Med.- 1997.- Vol. 102.- P. 252 258.

5. Graus F., Rogers L.R., Posner J.B. Cerebrovascular complications in patients with cancer // Medicine.- 1985.- Vol. 64.P. 16-35.

6. Gundersen H., Moynihan B. An uncommon cause of stroke: non-bacterial thrombotic endocarditis // J. Stroke Cerebrovascr. Dis.- 2016.- Vol. 25 (10).- P. e163-e164. doi: 10.1016/j.jstrokecerebrovasdis.2015.11.009.

7. Habib G., Lancellotti P. Antunes M.J. et al. 2015 ESC Guidelines for the management of infective endocarditis: The Task Force for the Management of Infective Endocarditis of the European Society of Cardiology (ESC) Endorsed by: European Association for Cardio-Thoracic Surgery (EACTS), the

\section{Висновки}

Небактерійний тромботичний ендокардит є серйозним ускладненням низки хвороб, серед яких автоімунні захворювання та онкологічна патологія. У пацієнтів із групи ризику необхідний ехокардіографічний скринінг на предмет виявлення тромботичних вегетацій, які загрожують системними емболіями.

У пацієнтів із системною емболією нез'ясованого генезу на шляху діагностичного пошуку потрібна трансторакальна ехокардіографія, а при сумнівних результатах дослідження або підозрі на небактерійний тромботичний ендокардит - черезстравохідна ехокардіографія, яка дозволяе виявити специфічні ознаки небактерійного тромботичного ендокардиту. При виявленні небактерійного тромботичного ендокардиту необхідний пошук основної патології (автоімунної хвороби або онкологічного захворювання).

Лікування небактерійного тромботичного ендокардиту передбачає антикоагулянтну терапію та лікування основного патологічного процесу, який спричинив формування тромботичних вегетацій.

European Association of Nuclear Medicine (EANM) // Eur. Heart J.- 2015.- Vol. 36 (44).- P. 3075-3128.

8. Ito S., Yoshitomi H., Pak M. et al. Trousseau syndrome with nonbacterial thrombotic endocarditis in a patient with uterine cancer // Internal. Medicine.- 2013.- Vol. 52 (12).P. 1353-1358. doi: 10.2169/internalmedicine.

9. Kaufmann C.C., Wessely E., Huber K. Non-bacterial thrombotic endocarditis in the context of pulmonary adenocarcinoma: a case report // Eur. Heart J.- Case Reports.- 2020.Vol. 4 (1).- P. 1-5. doi: 10.1093/ehjcr/ytaa008.

10. Key N.S., Khorana A.A., Kuderer N.M. et al. Venous thromboembolism prophylaxis and treatment in patients with cancer: ASCO Clinical Practice Guideline Update // J. Clin. Oncol.2020.- Vol. 38 (5).- P. 496-520. doi:10.1200/JCO.19.01461.

11. Kotkar K.D., Said S.M. Libman-sacks endocarditis in a patient with antiphospholipid syndrome // Ann. Thorac. Surg. 2016.Vol. 102.- P. e31-32.

12. Llenas-Garsia J., Guerra-Vales J., Montes-Mopreno S. et al. Nonbacterial Thrombotic Endocarditis: Clinicopathologic Study of a Necropsy Series // Rev. Esp. Cardiol.- 2007.Vol. 60 (5).- P. 493-500. doi: 10.1016/S1885-5857(07)60190-x.

13. Merkler A.E., Navi B.B., Singer S. et al. Diagnostic yield of echocardiography in cancer patients with ischemic stroke // J. Neurooncol.- 2015.- Vol. 123.- P. 115-121.

14. Navi B.B., Singer S., Merkler A.E. et al. Recurrent thromboembolic events after ischemic stroke in patients with cancer // Neurology.- 2014.- Vol. 83.- P. 26-33.

15. Navi B.B., ladecola C. Ischemic stroke in cancer patients: A

\section{证}


review of an underappreciated pathology // Ann. Neurol.2018.- Vol. 83 (5).- P. 873-883. doi: 10.1002/ana.25227.

16. Pepi M., Evangelista A., Nihoyannopoulos P. et al. Recommendations for Echocardiography in the Diagnosis and Management of Cardiac Sources of Embolism // Eur. J. Echocardiogr.- 2010.- Vol. 11.- P. 461-476.

17. Roldan C.A., Sibbitt W.L.Jr, Qualls C.R. et al. Libman-Sacks endocarditis and embolic cerebrovascular disease // JACC Cardiovasc. Imaging.- 2013.- Vol. 6 (9).- P. 973-983. doi: 10.1016/j.jcmg.2013.04.012.

18. Sakima H., Isa K., Kokuba K. et al. Recurrent embolic stroke due to nonbacterial thrombotic endocarditis followed by transesophageal echocardiography // Arch. Neurol.- 2011.Vol. 68 (12).- P. 1604-1605. doi: 10.1001/archneurol.2011.687.

19. Saric M., Armour A.C., Arnaout M.S. et al. Guidelines for the
Use of Echocardiography in the Evaluation of a Cardiac Source of Embolism // J. Am. Soc. Echocardiogr.- 2016.Vol. 29 (1).- P. 1-42. doi: 10.1016/j.echo.2015.09.011.

20. El Shami K., Griffiths E., Streiff M. Nonbacterial thrombotic endocarditis in cancer patients: pathogenesis, diagnosis, and treatment // The Oncologist.- 2007.- Vol. 12 (5).- P. 518-523. doi: 10.1634/theoncologist.12-5-518.

21. Shao B., Wahrenbrock M.G. Yao L. et al. Carcinoma mucins trigger reciprocal activation of platelets and neutrophils in a murine model of Trousseau syndrome // Blood.- 2011.Vol. 118 (15).- P. 4015-4023. doi: 10.1182/blood-2011-07368514.

22. Yoo J., Choi J.K., Kim Y.D. et al. Outcome of Stroke Patients with Cancer and Nonbacterial Thrombotic Endocarditis // J. Stroke.- 2020.- Vol. 22 (2).- P. 245-253. doi: 10.5853/ jos.2020.00619.

\section{Н.Д. Орыщин}

Львовский национальный медицинский университет имени Данила Галицкого

КЗ ЛОС «Львовский областной клинический лечебно-диагностический кардиологический центр»

\section{Небактериальный тромботический эндокардит как причина системной эмболии}

В статье описан клинический случай небактериального тромботического эндокардита у пациентки с ишемическим инсультом эмболического происхождения. Методы визуализации (трансторакальная и чреспищеводная эхокардиография) позволили выявить специфические признаки тромботических вегетаций на митральном и аортальном клапанах сердца. Лабораторные методы диагностики (посев крови, серологическое исследование) исключили инфекционный эндокардит как причину вегетации. В результате диагностического поиска (компьютерная томография) выявлены первичное новообразование легких с вторичными очагами в костной системе. Представленный случай демонстрирует потребность настороженности относительно небактериального тромботического эндокардита у пациентов с явлениями системной эмболии и в специфических группах больных (аутоиммунная и онкологическая патология).

Ключевые слова: небактериальный тромботический эндокардит, марантический эндокардит, эхокардиография, системная эмболия.

\section{N.D. Oryshchyn}

Danylo Halytsky Lviv National Medical University, Lviv, Ukraine Lviv Regional Clinical Medical and Diagnostic Cardiology Center, Ukraine, Lviv, Ukraine

\section{Nonbacterial thrombotic endocarditis as a cause of systemic embolism}

We presented a clinical case of the non-bacterial thrombotic endocarditis in a patient with ischemic stroke of embolic origin. Imaging methods (transthoracic and transesophageal echocardiography) showed specific features of thrombotic vegetations on mitral and aortic heart valves. Laboratory work-up (blood culture, serological examination) excluded infective endocarditis as a cause of vegetations. Diagnostic work-up with computed tomography showed lung tumor with metastatic foci in bones. Presented case demonstrates need for awareness regarding nonbacterial thrombotic endocarditis in patients with systemic embolism and in specific groups of patients (autoimmune diseases and oncology).

Key words: nonbacterial thrombotic endocarditis, marantic endocarditis, echocardiography, systemic embolism. 